\title{
Erindringer fra Frøslevlejren og Fårhuslejren
}

\section{af Asger Hansen}

Meget få har indefra oplevet både Frøslevlejren - interneringslejren for de naziforfulgte 1944-45 - og Fårhuslejren, hvor man samlede slandssvigerne巛 i årene 1946-49.

Asger Hansen, født i Fogderup 1921 og senere cand. psych. og seminarierektor, sad i Frøslev som modstandsmand og var derefter 1946-49 i Fårhuslejren som fængselslærer. Her fortæller han personlige minder fra de to vidt forskellige ophold på samme sted.

At huske er ikke nogen tilfældig proces. Al hukommelse er selektiv (udvælgende). Man husker det, man mener, har haft betydning for en selv og er tilbøjelig til at forbigå det øvrige. Det er usikkert, om »hukommelsesproduktet« entydigt udtrykker det, som egentlig fandt sted, eller om det er et resultat af en senere forarbejdning.

Denne beretning bygger hovedsageligt på usystematiske hukommelsesrester fra en tid, der ligger et lille halvt århundrede tilbage. Man kan derfor næppe tillægge det skrevne ret megen »objektiv“ historisk værdi, men må betragte det som en nødtørftig beskrivelse af hændelser, således som de foreligger i min erindring, men dog som hændelser, der dengang de fandt sted, gjorde et stærkt indtryk på et ungt menneske $\mathrm{i}$ tyverne.

Jeg er antagelig den eneste nulevende dansker, der har et direkte kendskab til både Frøslevlejren og Fårhuslejren. I førstnævnte sad jeg som det tyske politis fange fra lejrens åbning midt $i$ august 1944 til få dage før kapitulationen, og i den anden fungerede jeg som fængselslærer i tre år fra september 1946.

Som anført er det hovedsageligt min hukommelse, der har leveret stof til beretningen. Jeg har dog hentet talmæssige oplysninger vedrørende Frøslevlejren fra: "Fanger i Frøslevlejren 1944-45« ved Jørgen Mågård (Nationalmuseet 1974). Hvad angår retsopgøret efter kapitulationen har jeg brugt Poul Hammerichs: »En danmarkskrønike 1945-72« bd. 1 (Gyldendal 1976) samt tidsskriftet "Frie ord ( (Gyldendal), der kom i årene 1946-48 under redaktion af Vilhelm Grønbech og Hal Koch. Begge publikationer giver udtryk for synspunkter, jeg dengang vedkendte mig, og som - stort set - også er mine i dag.

\section{Fange i Frøslev}

Tiden er den 14. august 1944. Dagen er endnu ikke begyndt. Om aftenen den 13. lagde det "gode« skib "Mars« til kaj i Flensborg havn efter godt 1 1/2 
døgns sejlads fra Helsingør. Lasten havde været ca. 750 "frihedskæmpere«, der kom fra den overfyldte Horserødlejr, hvor de var blevet taget $i$ forvaring af den tyske besættelsesmagt, fordi de havde haft for svært ved uden videre at affinde sig med samme magts mere end fireårige huseren $i$ landet. Jeg selv var en af de 750 .

Danmark havde siden den 29. august 1943 været uden regering, men løbende administrative statsfunktioner blev forestået af en samling departementschefer, det såkaldte departementschefstyre. Gennem forhandlinger i foråret 1944 var det lykkedes for departementschefstyret at få tyskernes accept af, at der blev opført en lejr, der kunne rumme ca. 1.500 fanger. Tyskerne havde betinget sig, at lejren blev placeret i nærheden af den dansk-tyske grænse, så lejrens indhold med lethed kunne overføres til fængsler og lejre i Tyskland i tilfælde af en allieret invasion længere oppe i Jylland.

Lejren blev opført i løbet af sommeren i Frøslev plantage, nogle få kilometer nord for grænsen. Fra dansk side havde hensigten været, at deportationen af danske borgere til tyske straffeanstalter, der var vokset foruroligende, skulle standses, ja, der gik tilmed rygter om, at danskere, der hensad i tyske fængsler og lejre (dog med undtagelse af jøder), skulle føres tilbage til Danmark for at afsone, hvad de endnu måtte skylde det tyske rige. Ak ja, det skulle komme til at gå meget anderledes.

Men tilbage til »Mars«. Ved aftenstid den 11. august var evakueringen af Horserødlejren begyndt, og den fortsatte gennem det meste af natten. Vi fanger blev stuvet under dæk straks ved ankomsten til Helsingør. Den danske lejrforvaltning havde inden afrejsen forsynet os med rigelige madpakker. Mad var også det eneste, der var rigeligt af. De alt for få, tilmed uhumske, køjer, der stod til vor rådighed, blev fordelt mellem de ældste - eller taget i besiddelse af de mest bjergsomme yngre fanger.

Jeg selv plus fire til fem andre "Häftlinge« havde sat os nær den lejder, der førte op til det hul i dækket, der var vores eneste adgang til det fri fra lastrummet. Vi sad umageligt på dørken de næsten to døgn, overfarten til Flensborg varede, bortset fra de to gange under overfarten, hvor der blev givet tilladelse til kortvarige dæksbesøg.

"Mars« fremtrådte som en stærkt ramponeret repræsentant for den tyske krigsmagt. Jeg gatter på, at den i sine velmagtsdage har gjort tjeneste som lastskib i den tyske handelsflåde, og at den, da fæedrelandet kaldte på den til mere heroiske maritime bedrifter, $i$ hast og nødtørftigt blev ombygget til troppetransportskib. Næsten ingen installationer kunne virke efter deres hensigt. Vi henlå derfor $\mathrm{i}$ hel- eller halvmørke $\mathrm{i}$ en så beklumret luft, at den måtte lede tanken hen på den luft de vordende negerslaver måtte indånde på slaveskibene på deres vej mellem Afrika og Amerika i 17-1800-tallet. 


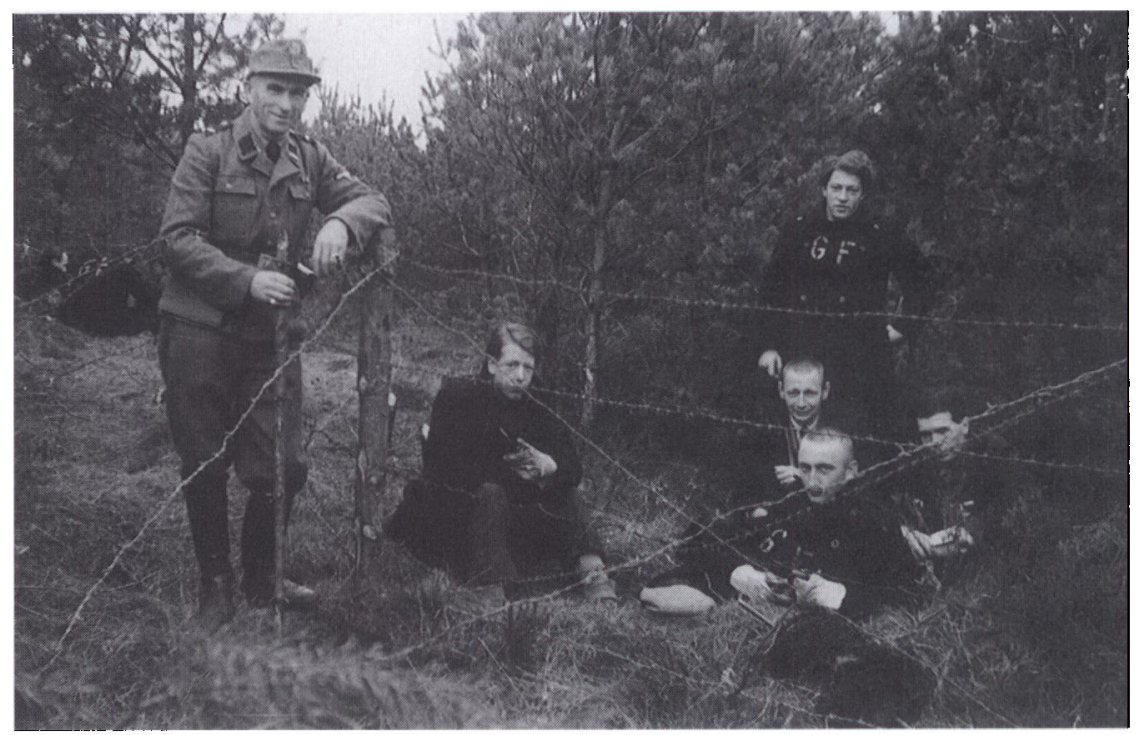

En gruppe Froslevfanger er udkommanderet til at trakke pigtråd i plantagen uden for lejren. Bemark det påtrykte »GF" på fangernes arbejdstoj. Det stod for „Gefangenenlager Froslew. Foto i Museet for Froslevlejren.

Jeg var mellem de sidste fanger, der forlod transportskibet. De få tyskere, der stod ved kajen, da vi lagde til, og som havde råbt ukvemsord efter os, var forlængst gået hjem.

Jeg husker tydeligt det lurvede og nedslidte indtryk af Flensborg, der slog os i møde, da vi drog nordpå igennem byen mod grænsen. Jeg havde sidst set Flensborg i sommeren 1939 i forbindelse med det danske årsmøde. Forandringen var overvældende.

Var Flensborg trøstesløs, var Frøslevlejren det ikke mindre, men på en helt anden måde. Lejren fremtrådte ikke nedslidt, men ufærdig, dog med et præg af at være en rigtig koncentrationslejr. $I$ en rydning midt $i$ granplantagen lå spredt et utal af rødmalede træbarakker, hvoraf adskillige endnu ikke syntes færdige til at tages i brug. Alt var hegnet ind med flere meter højt pigtråd. I høje vagttårne sad bevæbnede vagter. Terrænet omkring barakkerne mindede mest af alt om et månelandskab. Det blev sagt, at Frøslev plantage for en stor dels vedkommende lå på en oprindelig vandreklit, og sand og lyng var der $\mathrm{i}$ hvert fald rigeligt af.

De kammerater, jeg havde boet på stue sammen med i Horserød, var forlængst ankommet til lejren og sov antagelig sødt ovenpå rejsens besvær, jeg vidste bare ikke hvor. Det lettede om formiddagen, da jeg fandt dem. De var blevet indkvarteret $i$ barak 12 stue 4 og havde heldigvis holdt en plads til mig. 
Stuens indvånere udgjorde en gruppe, der på mange måder adskilte sig fra lejrens øvrige indbyggere. I gruppen var der københavnske arbejdere, hovedsagelig med bopæl på Nørrebro, akademikere (et par stud. polit.'er, Torben Kirstein og Hans Erik Thrane) samt nogle andre, som vi i dag vel nærmest ville betegne som intellektuelle: syndikalisten Carl Heinrich Petersen, der engang i 70'erne blev æresdoktor ved Aarhus universitet for sine studier i arbejderbevægelsens historie, Børge Trolle, som jeg sidst så engang i 60'erne som medarbejder ved SF's daværende ugeblad, barberen Niels Jacobsen, der forlængst havde forladt saks, barberkost og ragekniv til fordel for den udø̣vende kunst (i dag er han fagforeningsfunktionær i kommunalarbejdernes forbund). Stærkest knyttede jeg mig nok til to nørrebroske arbejdere, kusken Knud Ellegård, der senere $i$ en kort periode indtil sin alt for tidlige død blev formand for SID før Hardy Hansen, samt havnearbejderen Bruno Nielsen, der for mig - med mine 23 års ubefæstede sjæl - kom til at stå som idealrepræsentanten for klassebevidste arbejdere. Jeg husker det milde bud fra Odense, Røde Hans (tilnavnet viste såvel hen til hårfarven som til ideologien), der hele to gange havde været arresteret af det danske politi for illegalt arbejde, men som på sin tilforladelige fynske facon havde reddet sig ud af politiets klør. Røde Hans meddelte dog stadigt til den, der gad høre på ham, at det danske politi var væsentlig mere whøjpandet/ end det tyske sikkerhedspoliti. Også Hans endte efter 1959 i SF. Sluttelig skal jeg nævne Alvar Vesterberg, oprindelig udlært maler, men nu redaktør af »Forældrebladet«, udgivet af Ellen Hørup, datter af Viggo Hørup. Bladet fremtrådte som støtteorgan for venstreorienterede opdragere.

Hermed har jeg i store trak gjort rede for det miljø, jeg - som noget af en pantsat bondestudent fra det sønderjyske - var havnet $i$, og som jeg befandt mig godt $i$.

Alle var glødende antifascister, ingen var nationalister, adskillige var bevidste Trotskister, og ingen af dem troede på, at Stalin havde tilført arbejderbevægelsen noget til gavn for den. Det var disse mennesker fra det revolutionære overdrev, der første gang åbnede mine øjne for, at det ikke var helt uberettiget at sætte et kursiveret lighedstegn mellem Stalin og Hitler. Den store verden begyndte at ane det, efter at rygterne om Khrusitjovs afsløringer på den 20. partikongres i 1956 blev kendt. Allerede i 1944 var Stalin og den russiske afart af kommunismen genstand for barak 12 stue 4's mistillid - en mistillid, der var så begavet fremført, at rygtet gik, at partikommunister havde forbud mod at indlade sig i diskussion med dem, der boede på stue 4 . De fleste rettede sig efter forbudet, men jeg husker, at Peter P. Rohde, engang hvor vi havde bedt ham om at fortælle noget om den engelske arbejderklasses historie og havde gjort ham opmærksom på, at det vist ikke var velset, at han talte for os, 
svarede, at ingen skulle bestemme, hvem han ville tale for. Vi holdt regelmæssigt møder på stuen med foredragsholdere, der var specialister på politiske eller almenkulturelle områder.

Men Frøslevlejren var andet end barak 12 stue 4 . Vi blev bevogtet af et mandskab, der stort set ikke var os fjendtligt indstillet, og som på dette tidspunkt af krigen så i øjnene, at den formentlig ville ende med et for nazismen uønsket resultat. Undtagelserne var nogle SS'ere og nogle soldater, der bar en vinkel på uniformsjakken, der fortalte, at de pågældende havde været medlemmer af nazipartiet før magtovertagelsen i 1933. Begge kategorier søgte vi at holde os på afstand af, hvilket ikke altid kunne lykkes.

Da Hitler kort før jul i 1944 indledte Ardenneroffensiven i et sidste desperat forsøg på at ændre krigslykken, blev bevogtningspersonalet dog hensat i en euforisk jubelstemning ved de fanfareklingende "Sondermeldungen «, hvori man meddelte offensivens kortvarige succes de første par dage. Til vor store tilfredshed tog udviklingen dog en drejning, der snart gjorde ende på jubelen.

Det var kendetegnende for Frøslevlejren, at fangerne ikke led nogen materiel nød. Den danske lejradministration, som vi til daglig kun havde sparsom kontakt med, havde ansvaret for vor kostforplejning og for vor beklædning. Kosten var, som den måtte være, kedsommelig, men så rigelig, at ingen led nød. Beklædningen bestod af et sæt undertøj, en lærredsskjorte, en kradsuldssweater, et par arbejdsbukser og en stortrøje. På trøjen og på bukserne var påmalet med store bogstaver et „GF«, der skulle betyde så meget som »Gefangenenlager Frøslev«. Det skulle være koldt, førend vi frøs i den mundering.

For at forhindre flugtforsøg, blev der rundt om lejren udlagt landminer. Minerne lå så tæt og var så vanskelige at få øje på, at det mig bekendt - ud af tretten flugtforsøg - ikke var lykkedes een eneste fange at flygte ad den vej. Tværtimod førte undvigelsesforsøg til lemlæstelser og død. Undvigerne hørte helt overvejende til de "asociale « (sortbørshandlende og subsistensløse småkriminelle), som det tyske Hilfspolizei (Hipo) havde taget i varetægt efter 19. sept. 1944, dagen, der indledte godt 8 måneders politiløs tid i Danmark. De "asociale«, der blev klippet med "hanekam «, boede i en barak for sig, blev hundset med af tyskerne på en helt anden og mere utiltalende måde, end den der almindeligvis blev os "anständige Leute" til del. Jeg husker en morgen, jeg blev vækket af en klagende lyd udenfor stuens vinduer. Lyden kom fra en hanekamsklippet, der havde forsøgt at opnå friheden gennem minefeltet, men som var blevet fanget $i$ det, og som havde slæbt sig ind i lejren med et næsten helt afrevet ben. Det lykkkedes os at få purret tyskerne.

En soldat fra den deling af minører, der udlagde landminer, tabte en dag en mine ved den nordre udgang fra lejren. Jeg stod med mit arbejdshold ca. 40 meter fra ulykkesstedet og så - ligesom i slowmotion - tingesten falde 
langsomt til jorden, derefter et glimt og en svag, opadstigende røg, da minen eksploderede og fik minøren til langsomt at segne til jorden med underlivet revet op. Vi løb til, men blev gennet væk af de øvrige soldater. Den ulykkesramte soldat blev transporteret væk, jeg tror over i sygebarakken, hvor danske læger i fangenskab tog sig af ham. Det lykkedes lægerne at redde mandens liv, og lejrledelsen viste sin taknemmelighed ved at give alle fanger tilladelse til at skrive et brev hjem.

Brevkontakten med hjemmene var ellers en sjalden foreteelse. Når jeg tænker tilbage, synes jeg, der ustandselig blev meddelt brev- og besøgsforbud, enten som straf for forhold udenfor lejren, eller fordi man fra tysk side var utilfreds med interne forhold. Vi vænnede os efterhånden til tanken om, at forbindelse med »de kære derhjemme« måtte vente til engang, når krigen var slut.

Een gang $\mathrm{i}$ en af de få rolige perioder, hvor besøgsforbudet var sat ud af kraft, blev jeg kaldt over til besøg af min far. Det var godt at se far igen, selv om vi næsten ikke vidste, hvad vi skulle sige til hinanden det kvarter, der var afsat til besøget, der var overværet af en dansk kollaboratør.

Alle fanger havde arbejdspligt. Indtil jul arbejdede jeg på et jordhold, der søgte at planere de genstridige lyngbakker, så lejrens interne trafik kunne lettes. Det var så som så med arbejdsindsatsen, der ikke blev større af, at

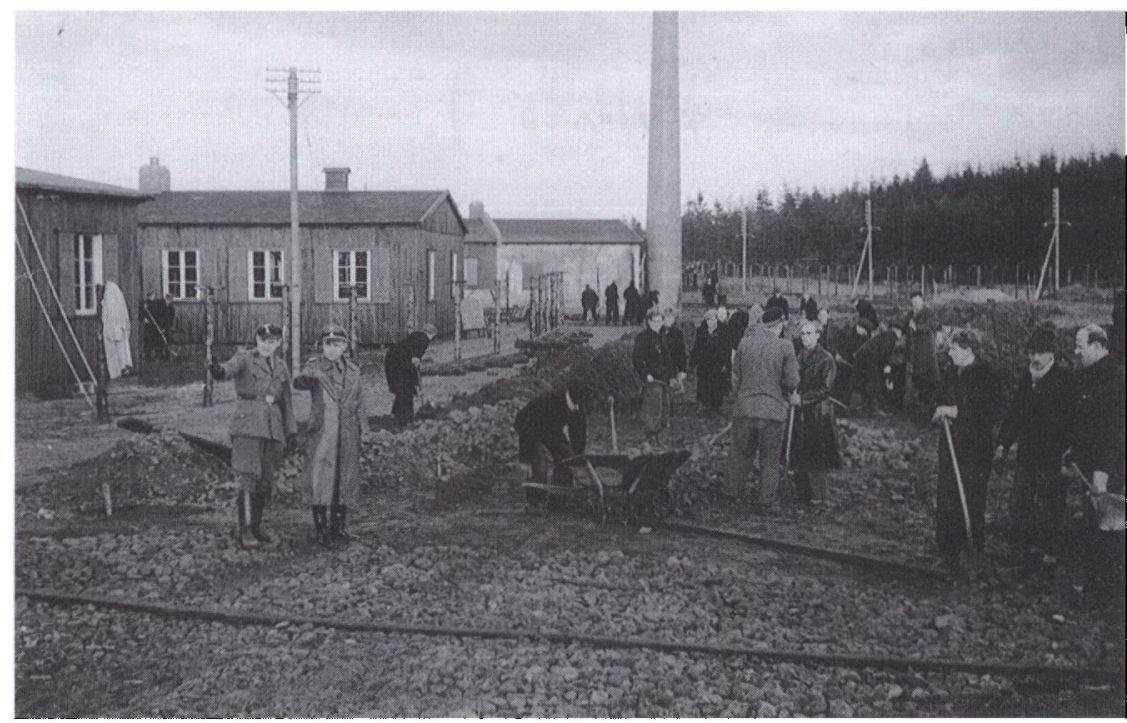

En gruppe Froslevfanger på gravearbejde inspiceres af lejrkommandanten SS-Sturmbannführer Hillgärtner (t.h.) og Hauptscharführer Klein. Foto i Museet for Freslevlejren. 
bevogtningsmandskabet ustandselig gav udtryk for deres utilfredshed med vore anstrengelser. Vi udviklede en slags døvhed overfor det unuancerede "los, los«, hvormed de søgte at animere vore arbejdsmæssige ydelser.

En dag i løbet af efteråret var Bruno, "Grønært« og jeg blevet sat til at foretage noget planeringsarbejde udenfor den »indre« lejr. Det var en vandkold efterårsdag, der ikke opfordrede til udendørs aktiviteter. Da vi ikke følte os overvågede, gemte vi vort værktøj under en tom barak, smuttede gennem et hul $i$ hegnet ind $i$ den indre lejr og begav os hjem til stuens tørverøgsfyldte hygge, hvor vi fordrev tiden med et slag bridge. Da det nærmede sig arbejdstids ophør, vendte vi tilbage til arbejdsstedet for at hente vore arbejdsredskaber og aflevere dem efter endt brug! Orden skulle der være $\mathrm{i}$ alt, hvad vi foretog os. Redskaberne var skubbet langt ind under den tomme barak, og jeg var på maven på vej ind for at hente dem, da jeg hørte et voldsomt brøl. Tynget af en ikke helt ren samvittighed dukkede jeg frem og blev modtaget af en frådende tysker, Klein, der midt $\mathrm{i}$ sin næsten olympiske forargelse havde svært ved at skjule sin glæde over at have snuppet tre Häftlinge i noget ulovligt. Klein var en af de tyskere, der var udsmykket med en vinkel på overarmen. Vi blev $\mathrm{i}$ hastigt tempo ført over til det tyske politikontor, hvor vi efter et kort forhør blev idømt tre eller fem dages mørkearrest på vand og brød. Så vidt, så godt. Vor høje dommer, Rothe, havde blot i sin forargelse overset, at lejren ikke på daværende tidspunkt var udstyret med en arrestbarak, hvorfor vi godt forgrinte kunne vende tilbage til vor stamstue.

En månedstid senere var straffebarakken imidlertid færdig til brug, og vi tre syndere blev en aften som de første puttet $i$ eneceller for dér at tilbagebetale "riget « den straf, vi skyldte det. Det var da blevet kold vinter. Vi var fra stuen blevet udstyret med cigaretter og tændstikker, som det lykkedes os at smugle ind $i$ vores ensomhed. Jeg sad på briksen og frøs med anstand, da en eller anden med eet skød slåen fra døren. Stor var min forbavselse, da det viste sig at være min medskyldige Bruno. Da han havde forsikret sig om, at vi var alene uden opsyn i barakken, var han brudt ud af sin celle og søgte nu at dække sit selskabsbehov ved at opsøge os to øvrige forbrydere. De fem dages isolation blev noget af det hyggeligste, jeg oplevede under mit Frøslevophold. Det var velgørende at være relativt alene, fri for det daglige store, uomgængelige fællesskab. Materielt led vi ingen nød. Straffebarakken blev brugt til modtagelse af nytilkomne, før de blev anbragt mellem andre Häftlinge, og da disse fik almindelig kostforplejning, tog madholdet rigelig mad med, som vi forsynede os af. Jeg erindrer endnu, at lommerne på min stortrøje en dag var fyldt med store stykker stegt lever. Kulden bekæmpede vi ved at bryde ind på et depot, hvor vi stjal masser af trælameller til sengebunde. De røg lige ind i den lille kakkelovn, der hørte til vor celle. Sådan blev kuldeproblemet løst. 
Idyllen under strafafsoningen havde vi dog nær sat til den dag, da lejrlederen, en ret utiltalende SS Sturmbannführer, havde fået det indfald at ville inspicere den nye straffebarak på et tidspunkt, hvor Bruno var på eftermiddagsvisit hos mig. Den »Meister«, der havde tilsynet med barakken, åbnede døren til min celle, men trak den skyndsomst til for næsen af Sturmbannführeren, da han i mørket havde anet, at alt ikke var, som det burde være. Vi nåede lige at høre Meisterens: "Alles in Ordning«, for parret fortsatte inspektionen.

Et kvarter senere, da Sturmbannführeren tilfreds havde trukket sig tilbage, kom en hvidglødende Meister tilbage og fortalte Bruno og mig, at han personligt var ligeglad med, hvad vi foretog os under afsoningen, men at han forlangte, at vi stillede en vagtpost ud, når vi på en eller anden måde, hvilken var ham "ganz egal«, ikke var, hvor vi skulle være. Hans holdning var ikke ualmindelig hos store dele af bevogtningsmandskabet, men var så uberegnelig, at vi fanger aldrig blev fritaget for usikkerheden og angsten for, hvem vi havde med at gøre.

Otte gange, første gang den 15. sept. 1944 og sidste gang den 15. febr. 1945, blev vi vækket k1. 3-4 om morgenen ved slag på den triangel, der hørte til hver barak. Triangelslagene blev ledsaget af ophidsede råb: "Aufstehen! Anziehen! Antreten! Schnell! Schnell! Los! Los! Ude på gangen ventede tyskerne på os, der søvndrukne var væltet ud af køjerne. Blandt tyskerne var Gestapo og SS-mænd - adskillige stærkt spirituspåvirkede. Når vi var på plads $i$ to rækker ned langs gangen, begyndte navneopråbet. Første gang anede vi ikke, hvad formålet med dette postyr var. Senere var vi klar over, at det drejede sig om udpegningen af de fanger, som skulle overføres til tyske lejre. Navneopråbene fandt sted i alfabetisk orden, sådan da. For nået gennem alfabetet, blev der oftest begyndt på en ny eller flere nye omgange. Udvælgelsen var fuldstændig tilfældig og kunne ramme såvel svært belastede modstandsfolk, som fanger, hvis indsats i modstandskampen havde været bagatelagtig. Ingen kunne føle sig sikker på at trække en nitte i lotteriet om liv eller død.

Een transport husker jeg særlig tydeligt. Den fandt sted den 5. oktober 1944. Hovedparten af de ca. 140 deporterede var grænsegendarmer, der var blevet arresteret den 19. september under aktionen mod det danske politi. Der blev fyldt op med 50 andre fanger. Vort indtryk var, at lejren havde fået frie hænder til under opfyldningen at gøre sig fri af »besværlige« fanger. På stue 4 i barak 12 var belægningen 12 fanger. 5 af disse kom med sydpå. Jeg husker den knugende fornemmelse at skulle sige farvel til 5 kammerater til en uvis fremtid, og jeg husker den - næsten lammende - sorgfulde tavshed, der fulgte efter afskeden. De 7 tilbageblevne på den ribbede stue havde det ikke godt i tomheden. Det var svært for dem at glæde sig over, at de var gået fri. Heller ikke alle de 5 nåede at komme hjem. 
Når man medregner et par mindre særtransporter, blev der fra Frøslevlejren $i$ alt deporteret godt 1600 fanger til tyske koncentrationslejre.

Det daglige liv i lejren kunne for en overfladisk betragtning forekomme ret sorgløst. Forplejningen var acceptabel og den arbejdspligt, der forelå, sørgede man selv for blev holdt på et rimeligt niveau, dvs. et niveau, som lå langt under tyskernes forventninger. Der forelå et tjenesteregulativ for opsynstjenesten med fangerne i lejren. Regulativet er i sin udforming meget "germansk « og meget restriktivt, men blev $i$ dagligdagen slet ikke efterlevet. F.eks. var det forbudt fanger fra een barak at besøge fanger $i$ de andre barakker. Jeg mindes ikke een dag, hvor jeg ikke har været $i$ en anden barak. Ifølge en anden bestemmelse vedrørende reglerne for besøg og modtagelse af pakker og breve var det forbudt fangerne at få bøger ind. Uagtet dette forbud var der rundt $i$ barakkerne mange illegale småbiblioteker, hvis bøger cirkulerede mellem fangerne, så længe de overhovedet var i stand til at hænge sammen. I februar måned 1945 blev der dog gennem Røde Kors oprettet et mindre fangebibliotek. Det var også forbudt at forsamles til andagt og gudstjenester. I al den tid, jeg var i lejren, har dette forbud været genstand for overtrædelse. Præster var der mange af i Frøslev, og de samlede folk om sig til andagt eller gudstjenester.

Megen af vor energi og vor tid som fanger blev anvendt på at gennemhulle reglementet. Vi var som en flok kostskoleelever, der ikke uden videre ville tilpasse os de regler for "god" opførsel, vore vogtere havde sat op.

Når jeg tænker tilbage på vor adfærd, må jeg indrømme, at den rummede mange regressive træk, som kan forekomme småbarnlige ud fra en »objektiv« betragtning, men som havde uomtvistelig betydning for os i vore bestræbelser på at hævde vor identitet overfor vore vogtere. Det var næppe for meget sagt, at denne daglige legen "kispus« med bevogtningsmandskabet var med til at give hverdagen et indhold, der både var underholdende og spændende.

Men overtrædelse af forbudene kunne også have fatale konsekvenser. Den 10. september 1944 blev fangerne samlet til appel nedenfor midtertårnet. Det blev meddelt os, at det var forbudt at nærme sig pigtrådshegnet $i$ en afstand af tre meter. Forbudet udløste en hånlig fælleslatter fra fangerne. Næste dag blev en fange, Preben Andersen, der uforvarende var kommet til at overskride den umarkerede grænse, beskudt og dræbt fra et af vagttåmene.

Den 8 . november 1944 var noget særligt i gære. Vi blev samlet på appelpladsen efter morgenmaden og fik at vide, at vi skulle grave tankspærringer syd for grænsen. Optællingen af fanger begyndte. Det viste sig helt umuligt at få antallet af de 700 fanger, aktionen omfattede, til at stemme. Vi stod på appelpladsen det meste af dagen, men blev sendt hjem, da tiden var blevet for fremrykket til at aktionen kunne iværksættes, men med besked om næste morgen at stille igen. $\mathrm{Nu}$ overlod mandskabet det til fangerne selv at føre 
regnskab med, hvem der skulle af sted. Ankommet til arbejdsstedet blev hver fange forsynet med en spade af så ringe kvalitet, at en lokal bondemand kørte i fast rutefart mellem arbejdsstedet og et værkstedsdepot for at udskifte knækkede spader med nye. Tre dage tilbragte vi med at knække spader, hvorefter vores medvirken blev opgivet.

To episoder fra tankspærringsgravningen skal kort refereres: Jeg tror, det var på operationens andendag, at den tyske leder af forehavendet truende meddelte, at den første fange, hvis spade knækkede, ville blive alvorligt straffet. Truslen blev fulgt af et øjebliks tavshed, der blev brudt - næsten larmende af bruddet på endnu et spadeskaft. Alle, der stod så nær, at de kunne høre den fatale lyd, drejede hovedet efter den. Stor var lettelsen, da bruddets ophavsmand viste sig at være en af de tyske opsynsmænd, der havde syntes, at gravningen gik for trægt og derfor havde villet demonstrere, hvordan der skulle arbejdes. Den uheldige skafteknækker blev ikke skudt, men fangerne på deres side følte, at de uhæmmet kunne fortsætte med at undergrave den tyske forsvarsindsats - hvilket de gjorde.

Den 11. november kl. 11 var datoen og det nøjagtige tidspunkt for våbenstilstandens ikrafttræden efter 1 . verdenskrig. Kort for klokken 11 gik der hviskende besked rundt fra mand til mand om at standse arbejdet og blotte hovederne og holde et minuts stilhed. Tyskerne så desorienterede ud, men holdt sig i ro det minut, mindehøjtideligheden varede. Den tysker, der stod nærmest mig, spurgte, om vi højtideligholdt en national mindedag. Jeg svarede, at det drejede sig om en mindedag for hele verden, nemlig mindet om den første verdenskrigs afslutning. "Ach so" var den eneste kommentar. Oplysningen sagde ham tilsyneladende intet.

Næste dag standsede udekommandoen uden nærmere forklaring fra tysk side. Vi ville helst tro, de knækkede spader var årsag til stoppet.

Hen på efteråret 1944 søgte tyskerne at få bugt med den voksende jyske jernbanesabotage ved at lade Frøslevfanger køre med i transporttog og lignende. Udtagelsen til disse "himmelfartskommandoer«, som de blev kaldt i lejrjargonen, var tilfældig. I hold på ca. 10 mand blev fangerne anbragt sammen med nogle vagter med henblik på at ryge i luften, hvis toget blev udsat for sabotage på dets færd op og ned gennem Jylland. Da »himmelfartskommandoerne « tilsyneladende ikke medførte noget fald $\mathrm{i}$ jernbanesabotagen, og da det heller ikke medførte noget tab af fanger, hørte disse "Sonderkommandoer« efterhånden helt op. Jeg nød ikke selv den ære at blive udtaget til nogen af disse udflugter, men af referater af kammerater, der deltog i dem, forstod jeg, at forløbet af og komforten under turen var helt afhængig af vagtmandskabets sammensætning: Nogle gav fangerne lejlighed til små indkøbsture under færden, med det resultat at deltagerne efter udflugterne, der i reglen varede nogle 
dage, kunne vende opmuntret tilbage efter at have haft kontakt med andre end tyskere og »Häftlinge«.

Mens jeg sidder og skriver dette, valter erindringerne ind over mig. Små glimt af episoder, der ofte får karakter af, at vi, de snedige og uefterrettelige fanger, drev gak med de "dumme« tyskere, of te med en indsats og med risici, vi slet ikke havde nogen indflydelse på. Oplevelsen af uhyggen, usikkerheden og angsten bliver der kun sporadisk givet plads for. Og det er rigtigt, at vi til daglig ikke talte om den - vel i et forsøg på at beskytte os mod den. Men som tiden er gået, og side om side med at oplevelserne er kommet på afstand, kan jeg overfor mig selv ikke benægte, at angsten vel optog en større del af min psykiske husholdning, end jeg dengang vidste af eller ville indrømme. Måske er den ustrukturerede og uformulerede angst for rædslerne ikke meget nemmere at bære end rædslerne er, når man møder dem direkte? Hvem ved?

De sidste måneder før Tysklands endelige sammenbrud var vi optaget af hvilken skæbne, der ventede os i forbindelse med denne. Gennem et par illegale radioer var vi til stadighed velinformerede om stillingen på fronterne. Alligevel svirrede rygterne helt ukontrollerede, optimistiske eller pessimistiske i en uoverskuelig blanding.

"Skrækrygterne« var i det aktuelle tilfælde rygterne om, hvad tyskene ville gøre af os, når englænderne eller russerne nærmede sig sydfra? Ville lejren blive genstand for en massakre? Ville vi blive jaget ud på vejene til en march nordpå til et mere sikkert opbevaringssted? Et rygte, som dog ikke vandt nogen videre tiltro, ville endda vide, at tyskerne satte så megen pris på os, at de havde planer om at deportere os til Norge. Om transporten skulle foregå fra Flensborg eller fra Frederikshavn, var der delte meninger om.

Frøslevlejren var bygget til at kunne huse 1500 fanger. Allerede i dec. 1944 blev dette tal overskredet til trods for, at der på dette tidspunkt fra lejren var ført ca. 1200 fanger sydpå. De sidste måneder eksploderede belægningstallet. Norske og danske fanger kom, takket være Bernadotteaktionen til Frøslevlejren, hvor de blev anbragt midlertidigt inden overførslen til Sverige. I april 1945 nåede belægningstallet op på ca. 5.600. Det kneb efterhånden katastrofalt med pladsen. Angsten for, hvad der skulle ske med os, tog noget af ved den kærkomne invasion af kammerater sydfra. Det var usandsynligt, at vi skulle massakreres, når så mange godvilligt blev videresendt til Sverige.

Jeg selv slap fri af jordholdet og fik et par måneders køkkentjeneste for derefter at ende på fangernes eget lejrkontor den sidste måned. Dér blev jeg og Knud Ellegård, som var fulgt med fra jordholdet, sat til at lave evakueringslister over fangerne, der blev inddelt efter geografisk tilhørsforhold, alder og civilstand, altsammen kombineret med vore oplysninger om køreplaner. Hvorledes det komplicerede arbejde kom til at virke i praksis ved jeg ikke, da 
jeg den 26. april var mellem de første oprindelige fanger, der forlod Frøslev med destination Sverige forude. Mit fangenskab var slut. At jeg først kom til Danmark en måned efter befrielsen, kan næppe lægges tyskerne til last, men skyldtes en skarlagensfeber med efterfølgende 5 ugers karantæne.

Det var en underlig fornemmelse at vende lejren ryggen d. 26. april 1945 med udsigt til om et par dage at være en fri mand udenfor tyskernes rækkevidde. Selvfølgelig glædede jeg mig over, at jeg havde været mellem de udvalgte, der slap fri. Heldigt, men ufortjent og lige så tilfældigt som tyskernes udvælgelse af dem, der blev deporteret sydpå. Vi ankom til Sverige den 27. april om aftenen efter en begivenhedsrig transport. Men lad det ligge. Afgørende var kun dette, at vi var fri.

\section{Fængselslærer i Fårhus}

Sommeren 1946 holdt jeg ferien hos mine forældre i Ravsted sammen med min kone og vor datter. Jeg havde studenterarbejde i Prisdirektoratet og spekulerede på efter ferien at genoptage min uddannelse, som var blevet afbrudt af mit virke i modstandsbevægelsen og den senere fængsling. Under ferieopholdet faldt jeg en dag i "Heimdal« over en artikel om straffelejren Fårhus, hvor der i løbet af et par måneder skulle startes undervisning af de fanger, der hensad i lejren dømt efter straffelovstillægget af 11. juni 1945. Det var antydet, at undervisningen bl.a. skulle sigte mod en demokratisering af de "vildførte«. Arbejdet lød meningsfuldt og spændende og kunne i sin art let konkurrere med min beskæftigelse i Prisdirektoratet, hvor jeg 8 timer om dagen beskæftigede mig med at sammenligne priskuranter for $»$ træemballage og træ opskåren til emballage«. På vej til København fra Sønderjylland traf jeg på Storebæltsfærgen Johs. Novrup, der som konsulent for ungdomsundervisningen var udpeget som rådgiver for fængselsundervisningen. Jeg kendte Johs. Novrup fra Askov Højskole. Han oplyste, at forstander Hjalmar Gammelgård havde overtaget jobbet som konsulent for fængselsundervisningen efter ham, hvorfor det var ham, jeg skulle henvende mig til. Heldet var ude. Besøget hos Gammelgård gav mig ikke alene den attråede stilling, men også et venskab med Gammelgård, der varede så længe han levede.

Klavs Villman, der var læreruddannet og desuden læste jura, var min kollega i Prisdirektoratet. Da han hørte om mine planer i Fårhus, syntes han, at det lød så spændende, at han tog med til Roskilde Højskole for at fremstille sig for Gammelgård og melde sig som ansøger. Sådan blev Klavs også fængselslærer.

På et par dages instruktionskursus i Audebolejren fik de mange ny fængselslærere lejlighed til at hilse på fængselsetaten, og de fik perspektiverne for deres 


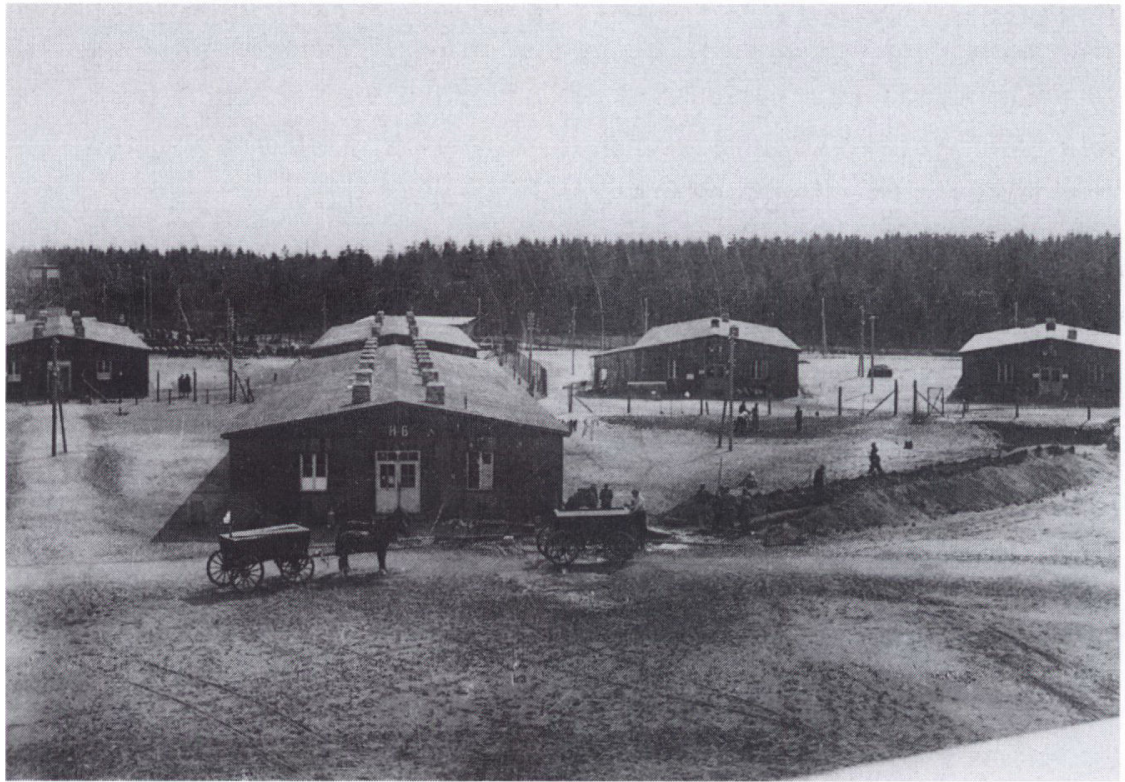

Fảrhuslejren kort efter kapitulationen, inden fangselsvasenet havde overtaget driften. Foto $P$. Clausen, Aabenraa. Historiske Samlinger for Senderjylland.

fremtidige arbejde ridset op. Mødet i Audebo var forjættende. Det startede under det fanfarelydende motto: Højskolen ind i fanglerne, og vi, de ny fængselslærere, begav os opløftede ud til de enkelte tjenestesteder med en god fornemmelse af, at et meningsfuldt pionerarbejde ventede os.

Gensynet med lejren var ejendommeligt. Da jeg i april 1945 sagde farvel til Frøslevlejren, havde jeg forestillet mig, at det var et farvel for altid og havde i hvert tilfælde ikke tænkt, at den dag ville oprinde, hvor jeg som frit menneske kunne bevæge mig ud og ind af portene.

Pigtråden, der markerede grænsen mellem inde og ude, var der stadigvak. Det var de bevæbnede vagttårne også, men nu var det ikke min færden, der skulle iagttages fra dem. Det truende minefelt var også forsvundet, og lejren fremtrådte sammenlignet med april 1945 for mig nærmest idyllisk og tækkelig. De grønklædte vagter var afløst af danske fængselsbetjente i mørke uniformer. Men i den indre lejr gik fanger rundt, der var iklædt en mundering, der kunne minde om vores dengang, dog uden de påmalede „GF « på bukser og jakker.

Straks efter vor ankomst blev Klavs og jeg ført til fremstilling for inspektør Gjerstrup. Han havde kontor i en af den ydre lejrs barakker. Kontoret var pompøst, egnet til at indgyde respekt. Tilbage i rummet sad Gjerstrup forskan- 
set bag et kæmpemæssigt skrivebord. Gjerstrups modtagelse af os var kontant, men blottet for hjertelighed. Jeg husker ordret de bemærkninger, der ved denne lejlighed faldt. Først et vurderende blik over vore personer, derefter lød det - lidt træt og opgivende: "Er det de ny lærere?« Vi sagde vore navne. „Det med undervisning af fangerne er direktoratets idé. Jeg tror ikke meget på den. Men nu kan De jo prøve. Bliver der nogle vanskeligheder, kan De altid henvende Dem til mig. Så kan De godt gå «.

Vi havde næppe ventet, at den røde løber var lagt ud for at modtage os, men velkomsten virkede nok lidt kontrapunktisk efter de forventninger, mottoet "højskolen ind i fangslerne" havde vakt i os på Audebomødet. I hvert fald kunne Klavs ikke, da vi igen stod udenfor inspektørkontoret, tilbageholde bemærkningen: »Det var måske dumt af os, at vi ikke løste en returbillet, før vi tog herned. « Det skal om Gjerstrup dog retfærdigvis siges, at i de tre år, vi arbejdede under hans ægide, mødte vi aldrig uønsket indblanding $i$ undervisningen fra hans side. Tværtimod. I de få tilfælde der var optræk til konfrontationer mellem skole og opsynspersonale, var han en salomonisk formidler af modsætningerne og slet ikke på forhånd indstillet imod skolen.

Det var hårdt at være i Fårhuslejren. De første to år måtte jeg lade min familie blive tilbage i København. Vi arbejdede alle ugens 7 dage (om søndagen censurerede vi breve) og havde så til gengæld 5 samlede fridage een gang om måneden, en frihed, vi kunne benytte til at besøge familien. Fra september 1948 blev jeg tildelt et funktionærhus. Det var godt for familielivet.

Lærerstaben bestod af en fængselsoverlærer, Hakon Kirkegård, der, så vidt jeg husker, havde forestået fritidsundervisningen på Frederiksberg, en tidligere højskolelærer Olav Nielsen, en fagskolelærer Stenholt-Laursen samt Klavs Villman og mig. Det var en ret uensartet gruppe, hvis medlemmer ikke kendte noget til hinanden, bortset fra Klavs og jeg. Jeg var den eneste lærer, der var helt blottet for undervisningserfaring.

De ca. 3.000 fanger bestod ved min ankomst af to omtrent lige store grupper, nemlig de, hvis sag var afsluttet med en domfældelse, og de, der ventede på en dom og altså sad i en slags varetægtsfængsel. Kun de, der havde fået en dom, kunne modtage undervisningstilbudet. Hver fange fik tilbud om 6 timers ugentlig undervisning $\mathrm{i}$ arbejdstiden fordelt på to blokke à 3 timer. Vi var ved tilmeldingen usikre på, hvor mange der ville tage mod tilbuddet, idet rygtet gik, at der blandt fangerne var stemning for at boykotte undervisningen $i$ harme over, hvad mange fanger opfattede som en uretfærdig behandling.

Tilmeldingen overgik imidlertid enhver forventning, så det blev nødvendigt at ansætte flere lærerkræfter. Jeg husker to cand. polit.'er, som jeg fik nære venskaber med, Thomas Rørdam, senere lærer på Rødding Højskole, og Ebbe Munk, senere lærer på Roskilde Højskole og til sin død på Esbjerg Højskole. 
Nogle rejste i løbet af de tre år, jeg gjorde tjeneste i lejren, indtil den blev nedlagt.

Før jeg går videre med at fortalle om Fårhuslejren, er det nødvendigt, at jeg siger et par ord om den generelle indstilling til landssvigerne, herunder min egen indstilling til retsopgøret.

Efter godt tre års besættelse, der ganske vist var præget af det officielle Danmarks samarbejdspolitik, gik regeringen af den 29. august 1943. De fleste danskere følte, at der efter dette tidspunkt eksisterede åben krigstilstand mellem Tyskland og Danmark, hvorfor ethvert samarbejde med besættelsesmagten blev betragtet som landsforræderi. De to sidste år af besættelsen var derfor præget af et indædt og blodigt opgør mellem modstandsbevægelsen og tyskerne samt disses håndlangere. Den tyske terror havde i befolkningen affødt et åbent behov for et opgør med de personer, der havde stillet sig til rådighed for besættelsesmagten. Månederne efter befrielsen blev præget af en stemning, hvori gengaldelsesmotivet havde en fremtrædende plads. Ialt blev der fængslet 34.000 personer mistænkt for landsskadelig virksomhed, og af disse blev ca. 15.000 idømt ubetingede fængselsstraffe. Straffelovstillægget adskilte sig på afgørende punkter fra den eksisterende straffelov: den genindførte dødsstraf for en række af de groveste forbrydelser, og den blev givet med tilbagevirkende kraft.

Den måned, jeg lå på hospital i Sverige efter befrielsen, og hvor jeg havde lejlighed til at læse danske aviser, fulgte jeg interesseret det oplæg til straffelovstillægget, der fremkom i pressen - jeg skriver med vilje oplæg, for diskussion var der næppe tale om. Jeg lå på en flermandsstue, hvor der til gengæld var masser af diskussion, og her stod jeg alene med mine betænkeligheder ved dødsstraffens genindførelse. Nødvendigheden af at give loven tilbagevirkende kraft kunne jeg derimod godt indse.

Men tilbage til Fårhuslejren. Det første, vi som lærere gjorde, var at foranstalte en standpunktsprøve i dansk og regning blandt alle tilmeldte. Resultatet af prøven fulgte stort set en normalfordeling. Fangerne blev inddelt efter prøveresultaterne kombineret med de undervisningsønsker, de havde fremsat ved tilmeldingen. Vi bemærkede, at et uventet stort antal ønskede at få undervisning i spansk. Her kunne man sikkert spore vage planer om en immigration til Sydamerika eller Spanien, som man mente havde et politisk klima i harmoni med egne idealer.

Efter de foran beskrevne indledende manøvrer kunne den egentlige undervisning begynde efter ca. en uge. Undervisningen omfattede elementærfagene dansk, regning og matematik, dertil sprogundervisning med engelsk og spansk som de foretrukne fremmedsprog.

Et af de hold, der var blevet mig tildelt, adskilte sig dog markant fra de 


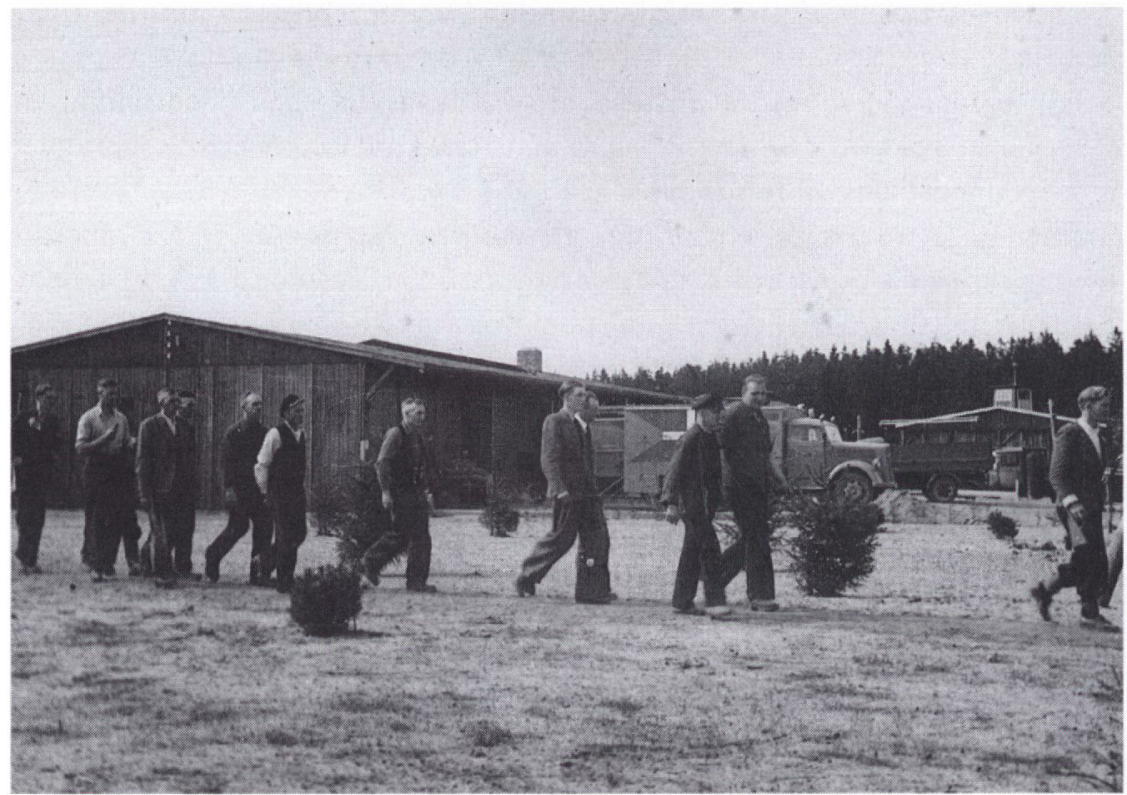

Internerede i Fårhuslejren 1945. Billedet er taget for efteråret 1945, da fangselsvasenet overtog driften. Th. Christensen foto. Historiske Samlinger for Sonderjylland.

øvrige. Det bestod overvejende af akademikere, jurister, historikere, journalister fra "Fædrelandet " og fra den tyskkontrollerede radio m.v. ${ }^{1}$ Et par af dem havde været medlemmer af det nazistiske storråd. Ingen af deltagerne havde ønsket elementærundervisning, men alle var opsat på at diskutere alment kulturelle og politiske emner.

Jeg husker tydeligt mit første møde med klassen. Jeg var med mine 25 år den yngste i klasserummet. Vi præsenterede os for hinanden. Jeg spurgte forsigtigt, hvad de havde tænkt sig, vi fremover skulle beskæftige os med i timerne. Svaret var, at de jo skulle demokratiseres, og at de var spændte på, hvad denne proces indebar. Jeg svarede med et modspørgsmål, der gik i retning af, hvad de forstod ved demokrati. Jeg husker ikke hvilket svar, jeg fik, men gang på gang fik jeg stillet spørgsmålet, hvad jeg som god demokrat mente om love med tilbagevirkende kraft. Det var selvfølgelig en fremstående jurist, der spurgte. Så var der inviteret til slagsmål! Den politiske diskussionstræning, jeg havde nemmet på stue $4 \mathrm{i}$ barak 12, kom mig nu til gode. To gange 3 timer om ugen fortsatte vi de politiske diskussioner uden at komme hinanden meget nærmere. Jeg var efterhånden blevet godt træt af at udveksle stereotypt gentagne argumenter med klassen, og den gav også udtryk for, at den efterhånden fandt underholdningen lidet givtig. 
I min bogreol havde jeg en lille populær-filosofisk bog stående. Den var skrevet af den svenske filosof Alf Ahlberg og hed "Tankelivets frigörelse» og beskæftigede sig med nogle elementære fejl, deltagere i den offentlige debat ofte gjorde sig skyld $i$. Bogen var en lille sag på knapt 200 sider. Jeg foreslog klassen, at vi gennemgik bogen kapitel for kapitel for at finde ud af, om vi i vores indbyrdes meningsudveksling kom ud for de beskrevne faldgruber. Forslaget vandt genklang hos hele klassen. Bogen var inddelt i 7 kapitler, der blev fordelt mellem 7 welever火. Fra landsbiblioteket i Aabenraa fik vi fremskaffet endnu et eksemplar af bogen, hvorefter det gik løs. Hele klassen, og her regner jeg mig selv med som deltager $\mathrm{i}$ klassens projekt, var efter en måneds forløb næppe til at kende igen. Mistillid, der let kunne antage karakter af åbent fjendskab, blev afløst af åbenhed og hjælpsomhed. I gennemgangen af Ahlberg stødte vi gang på gang på henvisninger til den betydning, renæssancen havde haft for den europæiske tankes udvikling. Da vi var nået til ende med »Tankelivets frigörelse«, blev vi enige om nærmere at beskæftige os med denne epoke. Hvad var dens historisk-politiske indhold, hvad havde den betydet kunstnerisk, litterært, malerisk og i billedhuggeriet? Religionen og reformationen blev heller ikke forbigået. Selv påtog jeg mig at gennemgå Dantes »Guddommelige komedie«, Boccaccios "Dekameron«, Petrarcas lyrik og til slut Cervantes "Don Quixote" samt udvalgte dramaer af Shakespeare.

Efter renæssancen kom turen til det klassiske Hellas efter den samme opskrift. Den historiske udvikling blev gennemgået, det samme gjaldt kunsten og arkitekturen, litteraturen fra Homér, Hesiodos, den græske lyrik til det udødelige græske drama. I næsten tre år levede jeg sammen med holdet $i$ vor fælles kulturarv.

Når fortiden lå for tung over os, foretog vi midlertidige afstikkere til mere aktuelle sfærer. Jeg husker særligt, at Helge Bangsted, den tidligere chefredaktor af naziorganet "Fadrelandet", fortalte om "Valbyparnasset«, som han i sine unge dage havde været medlem af sammen med andre ekspressionistiske lyrikere som Tom Kristensen og Emil Bønnelycke. Den tidligere leder af den tyske skole i Højer, Brochmann, holdt et kæmpeforedrag om europæiske mindretalsproblemer. Han var specialist indenfor området. Foredraget, der med spørgsmål og diskussion strakte sig over 12 timer, blev holdt på tysk og indeholdt et vald af oplysninger.

Da vi ikke kunne suge mere næring ud af Hellas, nærmede tiden sig for Fårhuslejrens nedlaggelse. Flere og flere af mine elever kunne nu gennem ændringer i straffelovstillægget påregne snarlige løsladelser, men vi nåede dog på falderebet at beskæftige os med nogle af verdenslitteraturens store. Jeg kan eksempelvis nævnte Moliere, Jonathan Swift, Lessing og Goethe.

I klassens forløb hændte det, at enkelte medlemmer blev løsladt og erstattet 


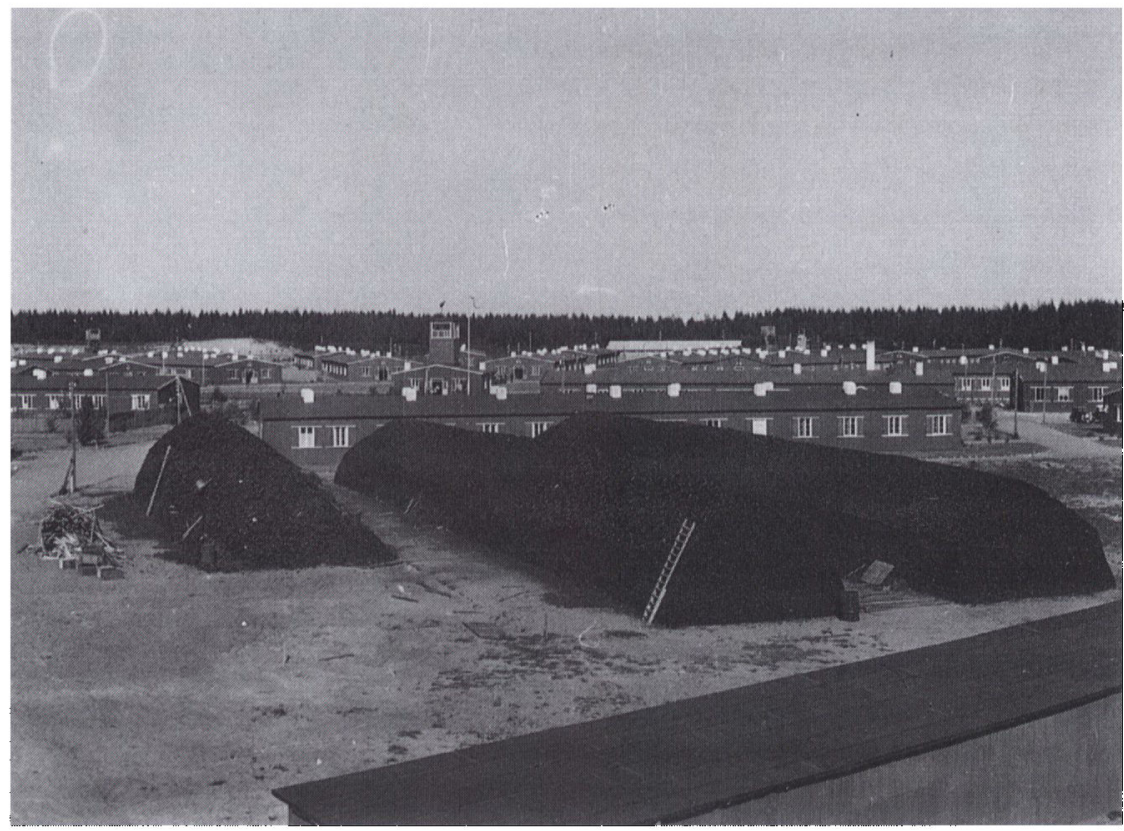

Färhuslejren. Oversigtsfotografiet her viser den "friserede k lejr, således som den fremtrådte, efter at det danske fangselsvasen havde fàet sat skik på den. Foto i privateje.

af nye. Flere af disse nye havde et behov for at genoptage debatten om berettigelsen af den straf, de var blevet idømt. Helt uden at jeg behøvede at blande mig i diskussionen, forklarede »de gamle« elever, at den debat havde de været igennem, at den for deres vedkommende var afsluttet, og at de havde noget mere væsentligt at beskæftige sig med i den tid, de var sammen $i$ skolestuen.

Jeg tror, at vi lærte meget af hinanden, landssvigerne og jeg. I en årrække, efter at Fårhuslejren forlængst var historie, modtog jeg breve og hilsener fra tidligere elever, der udtrykte deres taknemmelighed over "åndehullet «, som de benævnte fængselsskolen, og som havde været medvirkende til, at de på en bedre måde var kommet igennem en belastende tid, der ellers kunne have afsat varige sjælelige ar. Jeg selv lærte, at der til trods for næsten uoverskuelige forskelle af holdningsmæssig og ideologisk art er mulighed for at mødes $i$ noget fællesmenneskeligt. Det er ikke for meget sagt, at jeg rent bogstaveligt kom til at opleve nogle af de forhenværende nazikoryfæer som mine venner.

„Eliteklassen« var ikke den eneste klasse, jeg skulle undervise, og jeg var heller ikke den eneste lærer i lejren. Først lærerkollegiet. I en mandskabsbarak boede vi dør om dør i det første år. Al vor tid var helliget arbejdet. Megen 
tid blev beslaglagt af forberedelse til timerne, men mindst lige så megen tid blev brugt til kontakt med kollegerne. Alt var nyt for os. Vi måtte udveksle erfaringer fra undervisningen, erfaringer om fangerne og erfaringer om omgang med det øvrige personale. Det kan næppe nægtes, at personalet, og det gjaldt såvel det civile som det uniformerede, $\mathrm{i}$ begyndelsen ikke så med milde øjne på os. De stærke følelser og fordømmelsen af landssvigerne havde overvintret hos ganske mange i personalet, og de var tilbøjelige til at betragte "undervisningspåfundet« som et udtryk for dansk "pladderhumanisme«. Manglen på sympati fra det øvrige personale fik imidlertid lærerne til at stå yderligere sammen. Heldigvis blev der til skolen knyttet en velanskreven overbetjent, Gunnar Thomsen. Ham fik vi hurtigt tillid til. Han kunne fortælle os, hvad der rørte sig i betjentkorpset og give os stilfærdige råd om, hvilken adfærd fra vor side vi skulle anlægge for at undgå unødvendige provokationer. Det kunne ikke undgås, at fangerne bemærkede spændingerne, og de undlod da heller ikke at puste til ilden, når lejlighed var dertil. Vi fik god øvelse i balancegang.

Vinteren 46-47 var usædvanlig hård. Brændselsforsyningen (tørv) til lejren var mangelfuld, og en overgang var vi overbeviste om, at der blev gjort bevidste forsøg på at "fryse« skolen ud af lejren. Jeg husker timer, hvor jeg selv underviste, iført lange underbukser, islandsk sweater, skistøvler og overfrakke. Eleverne rystede af kulde, men jeg erindrer ikke, at så meget som een af mine timer blev aflyst.

Sammen med os i barakken boede det administrative personale. Dem fik vi hurtigt venskabelig kontakt med. Det samme var tilfældet med lejrens præst, pastor Peter Gadeberg fra Ensted, og efter hans afrejse med efterfølgeren, Erik Nissen, samt endelig i den tid han virkede, lejrlægen, Anders Schmidt, Augustenborg.

Jeg tror, det var en uvurderlig fordel for os lærere, at vi det første år var henvist til at bo i barak med de nævnte. De primitive forhold, vi alle boede under, henviste os til hinandens selskab, og de givne forhold blev udnyttet af begge parter til øget forståelse af hinandens synspunkter.

Lejrledelsen, inspektør Cuno Gjerstrup og viceinspektør Jens Klerens, var vi fra starten på afstand af. Vi mødte ganske vist ingen modstand fra de to herrers side, men heller ingen direkte inspiration eller støtte for vore anstrengelser. Forholdet bedredes dog kendeligt under forløbet, og det skyldtes hverken ideologiske eller direkte holdningsmæssige tilnærmelser, men derimod mere uigennemskuelige faktorer.

Både Klavs Villmann og jeg var gode bridgespillere. Gjerstrup og Klerens var ivrige og tilmed dygtige udøvere af samme kunst. Der blev etableret en bridgeklub, der mødtes en ugentlig aften til gensidig underholdning og ubarmhjertig følen-hinanden-på-tænderne. Af de gensidige dyster opstod en 
lige så gensidig respekt for modparten, og denne respekt havde - sikkert helt utilsigtet - en afsmitning på andre forhold. Sådan kan der ske så meget uforklarligt, hvor mennesker mødes. Stikpillerne parterne imellem blev med tiden mindre direkte og mindre hvasse. Om fangerne høstede nogen fordel af den større omgængelighed, har jeg ingen direkte indikation for, men fornemmelsen er der.

Efter mine tre år som fængselsłærer i Fårhuslejren kan jeg kun beklage, at jeg havde meget lidt indblik $i$, hvordan fangernes dagligdag forløb, når der ses bort fra selve undervisningen. Det var en uafviselig betingelse for, at vi lærere kunne få lov til at fungere, at vi holdt os indenfor det område, som snævert angik vores arbejde som "åndsapostle«. Men jeg er overbevist om, at vi i stigende grad indirekte bidrog til at humanisere behandlingen af strafafsonerne ved en sej, men uprovokerende påvirkning af klimaet.

I tiden efter Fårhuslejren har jeg ikke kunnet lade være med at spørge mig selv, om det tilbud, der blev givet fangerne gennem skolen, og det galder ikke alene Fårhuslejren, men også alle de øvrige afsoningssteder, har haft sin nok så beskedne andel $i$, at bitterheden antog et mindre omfang, end man kunne have befrygtet. Det er umuligt at frre noget holdbart sandsynlighedsbevis for en sådan antagelse. Jeg må bygge på usystematiske, men overraskende positive udtalelser fra tidligere »elever « - og dem har der været mange af. Jeg må dog indrømme, at jeg selv er en slags part $\mathrm{i}$ bedømmelsen, og at jeg ikke kan se bort fra, at min egen ønsketænkning kan spille en vis rolle ved vurderingen af forholdene.

\section{NOTER}

1. Fra dette melitehold« kan jeg i dag umiddelbart erindre en række navne. Når jeg ser dem, kan jeg $\mathrm{i}$ dag undre mig over, at jeg dengang med mine blot 25 år turde gå $i$ gang med opgaven: Helge Bangsted, chefredaktør ved det nazistiske dagblad »Fædrelandet«, Bjornvig, historiker, beskæftiget ved den tyskkontrollerede radio ("Vi bringer en kommentar«), Holger Bryld, cand. jur., direktør, nazistisk partileder, Tage Bryld, cand. jur., direktør, leder af DNSAP's pressetjeneste, Bjørn Erichsen, forlagsdirektør, Jespersen, radiokommentator, mden danske stemme fra Bremen", Ejnar Krenchel, overretssagfører, medarbejder ved den tyskkontrollerede radio, Erik Reitzel-Nielsen, landsretssagfører, formand for Juristforbundet, J. Strom, politiker H. Brochmann, skoleinspektør ved den tyske skole i Højer, Paul Koopmann, Dr., historiker, Arthur Lessow, leder af den tyske kommuneskole i Ravsted, $A$. Schau, tysk præst i Højer. 